\title{
Expression of the GBGT1 Gene and the Forssman Antigen in Red Blood Cells in a Palestinian Population
}

\author{
Wafa Ali Abusibaaa, c Mahmoud A. Srour ${ }^{a, h} \quad$ Ali-Reza Moslemi $^{b}$ \\ Lola Svensson $^{c}$ Carlos Jesus $^{d}$ Fernando Mendes ${ }^{d-g} \quad$ Camilla Hesse $^{c}$ \\ aDepartment of Medical Laboratory Sciences, Faculty of Health Professions, Al-Quds University, East Jerusalem, \\ Palestine; ${ }^{b}$ Department for Pathology, Institute for Biomedicine, Sahlgrenska Academy, University of Gothenburg, \\ Gothenburg, Sweden; ' Department for Clinical Chemistry and Transfusion Medicine, Institute for Biomedicine, \\ Sahlgrenska Academy, University of Gothenburg, Gothenburg, Sweden; ${ }^{d}$ Biomedical Sciences Department

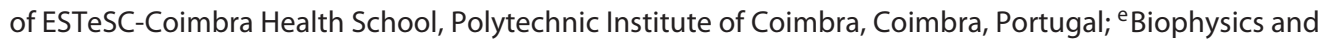 \\ Biomathematics Institute, IBILI-Faculty of Medicine, University of Coimbra, Coimbra, Portugal; ${ }^{f}$ CIMAGO, \\ FMUC-Faculty of Medicine, University of Coimbra, Coimbra, Portugal; ${ }^{9}$ CNC.IBILI, Universidade de Coimbra, \\ Coimbra, Portugal; ${ }^{\text {h}}$ Department of Biology and Biochemistry, Birzeit University, Birzeit, Palestine
}

\section{Keywords \\ Blood groups · Antigens · Genotyping · Forssman}

\begin{abstract}
Background: The Forssman antigen (FORS1 Ag) is expressed on human red blood cells (RBCs). We investigated its presence on RBCs from Palestinian subjects and Swedish subjects by serological testing and by sequencing part of exon 7 of the GBGT1 gene, which encodes Forssman synthase. Materials and Methods: Blood samples from Palestinian subjects ( $n=211$ adults and $n=73$ newborns) and from Swedish subjects ( $n=47$ adults) were analyzed in the study. RBCs from the Palestinian samples were typed for the FORS1 Ag using a monoclonal anti-Forssman antibody. The GBGT1 gene was genotyped by DNA sequencing (all adult samples) or by using amplification refractory mutation system PCR (newborn samples). Results: All of the studied samples were negative for the FORS1 Ag by serologic typing. DNA sequencing of the $3^{\prime}$ end of exon 7 of the GBGT1 gene, which includes Arg296, showed that all samples had the wild-type Arg296 sequence, which is associated with an inactive form of Forssman synthase. We detected four single nucleotide polymorphisms in the adult samples; two were silent
\end{abstract}

(p.Tyr232=, p.Gly290=), and two were missense (p.Arg243Cys, p.Arg243His). The allele frequencies ranged from 0.2 to $3.6 \%$. The p.Arg243Cys SNP was a novel SNP that was detected in one Palestinian sample. Conclusion: Our results confirmed the allelic diversity of GBGT1 and identified a novel nucleotide polymorphism in this gene, p.Arg243Cys. Our results also confirmed that the FORS blood group system is a low-frequency system.

(c) 2019 S. Karger AG, Basel

\section{Introduction}

The Forssman antigen (FORS1 Ag) was first described in 1911 by John Frederick Forssman [1]. It was identified after rabbits were injected with a suspension of guinea pig kidney tissue, and the rabbits produced antibodies (Abs) that could hemolyze sheep erythrocytes. Thus, the Ag on the sheep red blood cells (RBCs) was named the Forssman Ag (FORS Ag). In 2012, an A subgroup, $A_{\text {paee }}$, was the key to the discovery of Forssman (FORS1, ISBT System number 031) in human hematopoietic tissue $[2,3]$. A single heterozygous polymorphism, c.887G > A (p.Arg$296 \mathrm{Gln}$ ), was found in the GBGT1 gene, which encodes

\section{KARGER}

(c) 2019 S. Karger AG, Basel 
human Forssman synthase [3]. The substitution of glutamine for arginine allows the enzyme to bind to a UDPsugar (uracil-diphosphate sugar) donor and to catalyze the addition of a terminal 3- $\alpha-\mathrm{N}$-acetylgalactosamine to its globoside acceptor [4].

The human GBGT1 gene is located on chromosome 9 (9q34) and comprises 347 amino acids [5]. This gene has seven exons that span more than $8 \mathrm{~kb}$ of DNA, and the coding region is shared by all species that are positive for the FORS Ag [5]. GBGT1 is homologous to $\alpha-1,3$ GalNAc ABO A transferase (45\% sequence identity) [6]. The FORS1 Ag cross-reacts with polyclonal blood group A antibodies due to the terminal $\alpha-1,3$ GalNAc residue but do not cross-react with monoclonal blood group A antibodies [6].

Only a few humans that express the FORS1 Ag on their RBCs have been identified [3], and the implication of this $\mathrm{Ag}$ in humans is not clear. The FORS1 Ag is suggested to be involved in pathogen recognition and in cell development and migration, and it is also expressed in cancer tissues [7-9]. Forssman Abs (anti-Fs) occur naturally. AntiFs react strongly (i.e., agglutinate and hemolyze) with Forssman-positive cells. Anti-Fs in plasma may bind complement and cause the intravascular lysis of transfused FORS1-positive RBCs [3]. Anti-Fs may have implications for transfusion medicine and organ transplantation [3]. The frequency of anti-Fs in humans is still unclear and might depend on the detection methodology $[10,11]$. The expression of Forssman Ag has been reported in several different human tissues, such as gastric epithelium, kidney, and lung $[12,13]$. The presence of the Forssman Ag has also been described in certain human embryonic tissues [14].

The frequency of the FORS1 Ag is probably very low, and no studies have investigated the prevalence of the FORS1 Ag or polymorphisms in the GBGT1 gene in a Palestinian population. Svensson et al. [3] screened 256 random blood donors in Sweden for the c.A887G polymorphism (p.Gln296Arg), and all donors had arginine rather than glutamine at codon 296. The GBGT1 gene is reported to have high allelic diversity [11]. This study investigated the prevalence of the FORS1 Ag using serological and genetic methods in adult and newborn Palestinian subjects and in Swedish blood donors.

\section{Materials and Methods}

\section{Study Population}

We recruited a limited study population of 211 healthy adult Palestinians (102 women and 109 men; mean age $20.5 \pm 2.5$ years, range 19-35). The subjects were from different cities in Palestine and were thus representative of different geographic areas of the country. We also collected blood samples from 73 healthy newborns (1-5 days old) at several hospitals in Hebron and Beit-Jala, two cities in West Bank, Palestine. Of the 73 samples, 48 cord blood samples were collected from the umbilical cord immediately after delivery, and the remaining 25 samples were collected by venipuncture. It cannot be excluded that the cord blood samples might have an addition of maternal blood.

The study also included 47 DNA samples from randomly selected Swedish blood group O donors. The samples were anonymized by transfusion medicine, Sahlgrenska University Hospital, prior to analysis in the study. All subjects who agreed to participate in the study were briefed about its aim and asked to sign an informed consent form. For newborns, the parents were briefed and signed the informed consent form. The study followed the principles of the Declaration of Helsinki for scientific research, and the Ethics Committee of Al-Quds University approved the protocol.

\section{ABO Grouping}

$\mathrm{ABO}$ and $\mathrm{Rh}(\mathrm{D})$ typing were performed using a standard tube method. Samples were graded macroscopically according to standard blood bank practice.

\section{FORS1 Antigen Typing}

Grouping for the FORS1 Ag was performed using monoclonal anti-Fs IgM that was concentrated from hybridoma cell culture supernatant (rat cell culture M1/22.25.8.HL; ATCC ${ }^{\circledR}$ TIB. 121 ${ }^{\mathrm{TM}}$ ). A small quantity of RBCs were washed three times using normal saline. Cord blood RBCs were washed five times as recommended by international guidelines to remove Wharton's jelly.

Equal volumes of a 3\% washed RBC suspension and monoclonal anti-Fs Ab were mixed and incubated for $1 \mathrm{~h}$ at room temperature. The samples were then centrifuged for $60 \mathrm{~s}$ at low speed $(200 \mathrm{~g})$. The reactions were graded macroscopically according to standard blood bank practice and international guidelines. Random samples were selected to be examined microscopically to verify the reactions or to confirm any macroscopic doubts. Kodecytes with an incorporated Forssman pentasaccharide $(50 \mu \mathrm{g} / \mathrm{mL})$ were used as a positive control [10]. The Forssman pentasaccharide was a gift from Dr. Stephen Henry of Kode Biotech.

\section{GBGT1 Genotyping}

The $3^{\prime}$ end of exon 7 of the GBGT1 gene was analyzed. This region harbors two gene-inactivating polymorphisms, c.688G $>A$ (p.Gly230Ser) and c.887A >G (p.Gln296Arg) based on the European Molecular Biology Laboratory (EMBL) sequence accession No. ENST00000372040 (which spans amino acids 220-347). The entire exon 7 was sequenced in seven samples, and exons 3-7 of the GBTG1 gene were sequenced in eight samples. Exon 7 from a FORS1-positive individual was sequenced as a positive control for the active GBTG1 gene (Gln296).

Genomic DNA was purified from buffy coat using the MasterPure $^{\mathrm{TM}}$ DNA Purification Kit (Epicentre, Chicago, IL, USA) and the Blood Version II kit. Target DNA sequences were amplified using a DNA Engine PTC-200 Peltier Thermal Cycler (Scandinavian Diagnostic Services Company). The PCR reaction was performed as follows: $100 \mathrm{ng}$ of genomic DNA, $1 \times$ PCR buffer, $1.5 \mathrm{mM}$ $\mathrm{MgCl}_{2}, 0.625$ units of ThermoPrime Taq DNA polymerase, $0.2 \mathrm{mM}$ of each dNTP, and $0.5 \mu \mathrm{M}$ of each reverse and forward primer (Table 1). Thermal cycling was performed as follows: initial denaturation at $95^{\circ} \mathrm{C}$ for $1 \mathrm{~min} ; 30$ cycles of $94^{\circ} \mathrm{C}$ for $30 \mathrm{~s}, 57^{\circ} \mathrm{C}$ for $30 \mathrm{~s}$, and $72^{\circ} \mathrm{C}$ for $1 \mathrm{~min}$; and a final extension step at $72^{\circ} \mathrm{C}$ for $5 \mathrm{~min}$. A no-template control (NTC) reaction was run as a negative control.

Since exon 7 is long and has high GC content, it was divided into three fragments (A, B, and $\mathrm{C})$; each fragment was amplified using a different primer pair, and only the exon $7 \mathrm{C}$ fragment (the $3^{\prime}$ part of exon 7) was sequenced for all samples (Table 1). PCR products were purified using the GeneJET PCR purification kit 
Table 1. Primers used in PCR analysis of exon 7 of the GBGT1 gene

\begin{tabular}{llll}
\hline Template & Primer orientation & Sequence $\left(5^{\prime} \rightarrow 3^{\prime}\right)$ & $\begin{array}{l}\text { Nucleotide } \\
\text { position }\end{array}$ \\
\hline Exon 7A & Forward & & Reverse \\
& Forward & CACACAGTGGGGACCCTG & $\begin{array}{l}14622-14639 \\
14835-14818\end{array}$ \\
\hline Exon 7B & Geverse & TTCTCAGCTCCATCCCCATC & $14816-14835$ \\
& Forward & CCCACCATAATAGAAGTCCCC & $15111-15091$ \\
\hline Exon 7C & Reverse & TTGGGAGACCTGGTGGCTGC & $14983-15002$ \\
& Common primer, reverse & GCCAGGCAGCCATG & $15377-15358$ \\
\hline Exon 7 & Mutant type primer, forward & CATCATGGCTGCCTGGCA & $15211-15198$ \\
& Wild primer, forward & CATCATGGCTGCCTGGCG & $15195-15211$ \\
\hline
\end{tabular}

ARMS, amplification refractory mutation system.

${ }^{1}$ RefSeqGen NG_033868.

Table 2. Summary of DNA variants in exon 7 of the GBGT1 gene in RBCs from Palestinian subjects showing the frequency and percentage of each SNP

\begin{tabular}{|c|c|c|c|c|c|c|c|c|}
\hline \multirow[t]{2}{*}{ SNP } & \multirow{2}{*}{$\begin{array}{l}\text { Variant position }{ }^{\mathrm{a}} \\
\text { Chr:bp }\end{array}$} & \multirow[t]{2}{*}{ rs ID ${ }^{b}$} & \multicolumn{3}{|c|}{ Frequency $(n=211)$} & \multirow{2}{*}{$\begin{array}{l}\text { Allele frequency } \\
\text { ( } n=422 \text { chromo- } \\
\text { somes), } \%\end{array}$} & \multirow{2}{*}{$\begin{array}{l}\text { PolyPhen- } 2^{c} \\
\text { prediction }\end{array}$} & \multirow[t]{2}{*}{ All allele No. ${ }^{\mathrm{d}}$} \\
\hline & & & $n$ & $\begin{array}{l}\text { hetero- } \\
\text { zygous }\end{array}$ & $\begin{array}{l}\text { homo- } \\
\text { zygous }\end{array}$ & & & \\
\hline c.727 C $\rightarrow$ T p.Arg243Cys & 9: 136029279 & rs759428295 & 1 & 1 & 0 & 0.2 & $\begin{array}{l}\text { Probably } \\
\text { damaging }\end{array}$ & Novel \\
\hline c. $728 \mathrm{G} \rightarrow \mathrm{A}$ p.Arg $243 \mathrm{His}$ & 9: 136029280 & rs143563851 & 4 & 4 & 0 & 1.0 & $\begin{array}{l}\text { Probably } \\
\text { damaging }\end{array}$ & $\mathrm{T}=10 / \mathrm{C}=12,996$ \\
\hline c. 696 C $\rightarrow$ T p.Tyr232= & $9: 136029312$ & rs34691037 & 2 & 2 & 0 & 0.5 & Unknown & $\mathrm{A}=374 / \mathrm{G}=12,632$ \\
\hline c. 870 C $\rightarrow$ T p. Gly $290=$ & 9:136029138 & rs35902535 & 14 & 13 & 1 & 3.6 & Unknown & $A=818 / G=12,188$ \\
\hline
\end{tabular}

a The location of the variant on the chromosome.

b rsids, the reference SNP identifier.

${ }^{c}$ A bioinformatics tool used to predict amino acid substitution on protein function (available from: http://genetics.bwh.harvard.edu/pph2/).

$\mathrm{d}$ The observed allele count in all populations [European American population (EA) and African American population (AA)]. All data were extracted from the Exome Variant Server program.

(Thermo Scientific, Waltham, MA, USA). Sanger DNA sequencing was performed using the BigDye ${ }^{\circledR}$ Terminator v1.1 Sequencing kit (Applied Biosystems, Foster City, CA, USA) and the products were purified using and ethanol/EDTA precipitation method. The purified sequencing reactions were run using the ABI PRISM 310 genetic analyzer (Applied Biosystems). DNA sequence files were analyzed using the BLAST program against the GBGT1 gene/ RefSeq with GenBank accession No. NG_033868.

For samples from newborns, 30 out of 73 were screened for the c.887G >A (p.Gln296Arg) polymorphism using amplification refractory mutation system (ARMS) PCR. Amplification was performed using the Accupower HotStart PreMix (Bioneer, South Korea). Briefly, $100 \mathrm{ng}$ of genomic DNA was mixed with primers (Table 1) to a final concentration of $0.25 \mu \mathrm{M}$, and the volume was brought up to $20 \mu \mathrm{L}$ with diethylpyrocarbonate water and added to the dried PreMix. Two tubes were run for each sample, one for the active gene product and the second tube for the inactive one. Thermal cycling was performed as follows: $94^{\circ} \mathrm{C}$ for $5 \mathrm{~min} ; 10$ cycles of $96^{\circ} \mathrm{C}$ for $15 \mathrm{~s}$ and annealing at $65^{\circ} \mathrm{C}$ for $1 \mathrm{~min} ; 20$ cycles of $95^{\circ} \mathrm{C}$ for $10 \mathrm{~s}, 61^{\circ} \mathrm{C}$ for $50 \mathrm{~s}$, and $72^{\circ} \mathrm{C}$ for $30 \mathrm{~s}$, and a final extension step of $72^{\circ} \mathrm{C}$ for $5 \mathrm{~min}$.

\section{Statistical Analysis}

All statistical analyses were performed using SPSS 20.0 (IBM Corp, Armonk, NY, USA). PolyPhen-2, a bioinformatics tool, was used to predict the amino acid substitution on protein function (available from: http://genetics.bwh.harvard.edu/pph2/).

\section{Results}

\section{$A B O$, Rh (D), and FORS1 Typing}

All samples were negative for FORS1 Ag by serological testing using monoclonal anti-Fs. Blood groups A (37\%) and $\mathrm{O}(36 \%)$ were the most common in the Palestinian subjects, followed by blood groups B (17\%) and AB (10\%).

\section{GBGT1 Sequencing}

The $3^{\prime}$ end of exon 7 was sequenced in all of the studied samples, and genomic DNA from one $\mathrm{A}_{\text {pae }}$ individual was 
Table 3. The prevalence of SNPs in exon 7 of the GBGT1 gene

\begin{tabular}{|c|c|c|c|c|}
\hline & \multicolumn{4}{|c|}{ SNP ID/allele frequency } \\
\hline & $\begin{array}{l}\text { c. } 870 \mathrm{C} \rightarrow \mathrm{T} \\
\text { p.Gly290= }\end{array}$ & $\begin{array}{l}\text { c. } 696 \mathrm{C} \rightarrow \mathrm{T} \\
\text { p.Tyr232= }\end{array}$ & $\begin{array}{l}\text { c. } 728 \mathrm{G} \rightarrow \mathrm{A} \\
\text { p.Arg } 243 \mathrm{His}\end{array}$ & $\begin{array}{l}\text { c. } 727 \mathrm{C} \rightarrow \mathrm{T} \\
\text { p.Arg243Cys }\end{array}$ \\
\hline \multicolumn{5}{|l|}{ Study populations } \\
\hline Palestinian samples $(n=211), \%$ & $6.6^{\mathrm{a}}$ & 0.95 & 2 & 0.5 (novel) \\
\hline Swedish samples $(n=47), \%$ & 4.3 & 0 & 0 & 0 \\
\hline ENSEMBL genetic variation $/ \mathrm{MAF}$ & 0.042 & 0.027 & 0.001 & Not listed \\
\hline Exome Variant Server ${ }^{\mathrm{C}} / \mathrm{MAF}$ & 6.2894 & 2.7856 & 0.0769 & Not listed \\
\hline \multicolumn{5}{|c|}{$\begin{array}{l}\text { Values are reported as the percentage of tested alleles in Palestinian and Swedish donors. MAF, minor allele } \\
\text { frequency. } \\
\text { a One positive sample was homozygous for c.870 C } \rightarrow \mathrm{T} \text {. } \\
\text { b ENSEMBL genetic variation; available from: http://asia.ensembl.org/Homo_sapiens/Gene/Variation_Gene/ } \\
\text { Table?db=core;g=ENSG00000148288;r=9:133152948-133163945 (accessed April 24, 2016). } \\
{ }^{c} \text { Available from: http://evs.gs.washington.edu/EVS/ServletManager?variantType=snp\&popID=AfricanAme } \\
\text { rican\&popID=EuropeanAmerican\&SNPSummary.X=35\&SNPSummary.y=10 (accessed May 2, 2016). }\end{array}$} \\
\hline
\end{tabular}

used as a positive control for active GBGT1 (c.887 G>A, p.Arg296Gln). DNA sequencing revealed that all samples had the c.688A (p.Ser230) and c.887 G>A, p.Arg296Gln polymorphisms. Additionally, four single nucleotide polymorphisms (SNPs) were found: two SNPs were silent polymorphisms c.696 C>T (p.Tyr232=) and c.887 G>A, p.Arg296Gln, and two SNPs were missense polymorphisms c.727 C>T, p.Arg243Cys and c.728G >A, p.Arg243His (Table 2). The unique SNP p.Arg243Cys was identified in 1 Palestinian woman. All of the polymorphisms were heterozygous except for one sample that was homozygous for the SNP p.Gly290=. Table 3 shows a comparison of the allele frequencies found in our study with results from other studies.

Out of the 73 newborn samples that underwent serological testing, 30 were analyzed using ARMS PCR. All had the inactive form (Arg296) of the GBGT1-encoded enzyme. The entire exon 7 of the GBGT1 gene was sequenced in three samples from newborns, and the results confirmed the presence of Gln296Arg plus a second known nucleotide substitution (p.Gly230Ser) in all studied samples.

\section{Discussion}

The Forssman Ag, which is one of the best-known heteroantigens, was recently reported to be present in normal human hematopoietic tissues [3]. This Ag has been found in fetal tissue and in several adult human tissues [12-14]. It has also been found in various cancer tissues [9]. FORS1 expression on RBCs could cause serious reactions in transfusions and transplantations, for example if anti-Fs Ab-positive plasma is transfused to a FORS1-positive individual. Many people have high titers of anti-Fs $\mathrm{Ab}[10]$. The present study specifically investigated the presence of FORS1 on human RBCs, including RBCs from newborns. This study also investigated the molecular aspects of the enzymes involved in FORS Ag synthesis.

We used a monoclonal anti-Fs IgM Ab from rat cell culture supernatant for FORS1 Ag grouping, which is a one-step, simple, and rapid method. Previously, the lectin Helix pomatia (HPL) has been used for Forssman grouping [9]. Although it has many advantages, HPL is not very specific, and it reacts with several structures, which could be a problem in blood banks. HPL can only be used for non-A blood groups. Alternatively, samples that are positive for FORS1 Ag by HPL could be further tested by anti-Fs Ab, because the sample could be an A Ag and/or an FORS1 Ag blood group. One problem with FORS1 Ag grouping is that it is difficult to find a positive control, as only a few individuals that express the FORS1 Ag on their RBCs have been identified. In this study, we used kodecytes to make sure that the anti-Fs Ab was working. However, since kodecytes are modified RBCs, one could argue that this is not a perfect control. All of the samples in our study were negative for the FORS $1 \mathrm{Ag}$, which is consistent with the GBGT1 genotyping results.

The best way to test for FORS1 positivity is to sequence the GBGT1 gene to detect the nucleotide substitution (p.Gln296Arg). Serological testing for the FORS1 Ag may not effectively discriminate between authentic FORS1 Ag and similar glycolipids [14]. The p.Gln296Arg polymorphism has been shown previously to be responsible for inactivation of Fs synthase, leading to FORS1 negativity in humans [5]. The reversion of this nucleotide substitution, i.e., the reversion to p.Arg296Gln, reactivates human Forssman synthase and has been detected in a few individuals who are FORS1 positive [3]. 
In this study, we found that the inactivating missense polymorphism (p.Gln296Arg) was present in all of the studied individuals, which confirmed the FORS1 Ag negativity that was determined by serological testing. We also found other missense and coding-synonymous polymorphisms that may be involved in Forssman synthase inactivation. The high allelic diversity of the GBGT1 gene has been reported previously [11]. One Palestinian sample had a unique missense polymorphism (p.Arg243Cys). This SNP could have a harmful effect on the GBGT1 gene product if it occurred independently of the two known mutations for FORS1 Ag negativity in humans, as predicted by the PolyPhen-2 bioinformatics tool. Further analysis is needed to determine the effect of this polymorphism on the GBGT1 gene and its possible relationship with different pathologies.

In conclusion, genotyping the $G B G T 1$ gene confirmed the presence of arginine at codon 296 (Arg296, wild-type) in the human version of the GBGT1-encoded enzyme in all studied samples. These findings were consistent with serological typing of the FORS1 Ag. An additional 4 SNPs were detected, one of which, p.Arg243Cys, was a unique SNP found in one Palestinian sample. Although this study was quite small, it confirmed that the FORS blood group system is a low-frequency system. It also confirmed the allelic diversity of the GBGT1 gene.

\section{Statement of Ethics}

The study followed the principles of the Declaration of Helsinki for scientific research, and the Ethics Committee of Al-Quds University approved the protocol.

\section{Disclosure Statement}

The authors have no competing interests.

\section{References}

1 Forssman JF. Die Herstellung hochwertiger spezifisher Schafhämolysine ohne Verwendung von Schafblut: Ein Beitrag Zur Lehre von heterologer Antikörpperbildung. Biochem Zeit. 1911;37:78-115

2 Stamps R, Sokol RJ, Leach M, Herron R, Smith G. A new variant of blood group A. Apae. Transfusion. 1987 Jul-Aug;27(4):3158.

3 Svensson L, Hult AK, Stamps R, Ångström J, Teneberg S, Storry JR, et al. Forssman expression on human erythrocytes: biochemical and genetic evidence of a new histo-blood group system. Blood. 2013 Feb;121(8):1459-68.

4 Hult AK. Studies of the ABO and FORS histoblood group systems: focus on flow cytometric and genetic analysis [dissertation]. Lund: Lund University; 2013.

5 Yamamoto M, Cid E, Yamamoto F. Molecular genetic basis of the human Forssman glycolipid antigen negativity. Sci Rep. 2012;2(1): 975.
6 Barr K, Korchagina E, Popova I, Bovin N, Henry S. Monoclonal anti-A activity against the FORS1 (Forssman) antigen. Transfusion. 2015 Jan;55(1):129-36.

$7 \mathrm{Xu} \mathrm{H}$, Storch T, Yu M, Elliott SP, Haslam DB. Characterization of the human Forssman synthetase gene. An evolving association between glycolipid synthesis and host-microbial interactions. J Biol Chem. 1999 Oct;274(41): 29390-8.

8 Young WW Jr, Hakomori SI, Levine P. Characterization of anti-Forssman (anti-Fs) antibodies in human sera: their specificity and possible changes in patients with cancer. J Immunol. 1979 Jul;123(1):92-6.

9 Lescar J, Sanchez JF, Audfray A, Coll JL, Breton C, Mitchell EP, et al. Structural basis for recognition of breast and colon cancer epitopes Tn antigen and Forssman disaccharide by Helix pomatia lectin. Glycobiology. 2007 Oct;17(10):1077-83.

10 Jesus C, Hesse C, Rocha C, Osório N, Valado A, Caseiro A, et al. Prevalence of antibodies to a new histo-blood system: the FORS system. Blood Transfus. 2018 Feb;16(2):178-83.
11 Hult AK, McSherry E, Möller M, Olsson ML. GBGT1 is allelically diverse but dispensable in humans and naturally occurring anti-FORS1 shows an ABO-restricted pattern. Transfusion. 2018 Aug;58(8):2036-45.

12 Hakomori S, Wang SM, Young WW Jr. Isoantigenic expression of Forssman glycolipid in human gastric and colonic mucosa: its possible identity with "A-like antigen" in human cancer. Proc Natl Acad Sci USA. 1977 Jul; 74(7):3023-7.

13 Breimer ME. Chemical and immunological identification of the Forssman pentaglycosylceramide in human kidney. Glycoconj J. 1985; 2:375-85

14 Houliston RS, Bernatchez S, Karwaski MF, Mandrell RE, Jarrell HC, Wakarchuk WW, et al. Complete chemoenzymatic synthesis of the Forssman antigen using novel glycosyltransferases identified in Campylobacter jejuni and Pasteurella multocida. Glycobiology. 2009 Feb;19(2):153-9. 